\title{
Mengukur Tingkat Pemberdayaan Masyarakat dalam Sektor Kesehatan
}

\author{
Measuring Community Empowerment Level in Health Sector
}

\author{
Ede Surya Darmawan, Purnawan Junadi, Adang Bachtiar, Mardiati Najib
}

Departemen Administrasi Kebijakan Kesehatan Fakultas Kesehatan Masyarakat Universitas Indonesia

\begin{abstract}
Abstrak
Pemberdayaan masyarakat adalah salah satu strategi dalam pembangunan kesehatan yang digunakan oleh pemerintah Indonesia. Pemberdayaan masyarakat ini menjadi salah satu fungsi puskemas yang wajib dijalankan oleh seluruh puskesmas di tanah air. Walaupun strategi pemberdayaan masyarakat sudah lama digunakan, sampai sekarang belum ada instrumen spesifik untuk mengukur tingkat pemberdayaan masyarakat pada sektor pembangunan kesehatan di Indonesia. Penelitian ini bertujuan untuk mengukur tingkat pemberdayaan masyarakat pada level komunitas sebagai wilayah kerja puskesmas di Depok dan Jakarta Selatan. Pemberdayaan masyarakat diukur menggunakan tujuh potensi masyarakat meliputi kepemimpinan, organisasi, dana, sumber daya, teknologi, pengetahuan, dan pengambilan keputusan. Metode pengukuran dilakukan dengan membandingkan ketujuh potensi masyarakat di wilayah kerja puskesmas di Depok (32 puskesmas) dan wilayah kerja puskesmas terpilih Jakarta Selatan (28 puskesmas) dengan potensi standar yang dikembangkan peneliti. Hasil penelitian memperlihatkan bahwa tingkat pemberdayaan masyarakat di wilayah kerja puskesmas di Depok umumnya banyak yang memenuhi kategori baik, sebaliknya di Jakarta Selatan banyak kategori kurang. Provinsi Daerah Khusus Ibu Kota Jakarta berupaya pemberdayaan masyarakat dan promotif preventif lebih mudah dilakukan oleh kantor kelurahan daripada puskesmas.
\end{abstract}

Kata kunci: Pemberdayaan masyarakat, pembangunan kesehatan, puskesmas

\section{Abstract}

Community empowerment is one of strategies in health development that is used by government of Indonesia. It is also one of puskesmas (primary health center) function that must be run by every primary health center in Indonesia. Though community empowerment has been used for a very long time, there is not any specific instrument to measure level of community empowerment in health sector development in Indonesia. This research aimed at measuring community empowerment at community level using neighbourhood association as work area in two cities in Indonesia, Depok and South Jakarta. Community empowerment is measured using seven community potentials including leadership, organizations, fund, resource, technology, knowledge, and decision making. The measurement method is comparing those community existed potentials with potential standard developed by researcher in 32 primary health center in Depok and 28 selected primary health center in South Jakarta. The result shows that level of community empowerment in primary health center work area in Depok is generally in good categories, but South Jakarta is generally in less category. In Jakarta, the effort of community empowerment and promotive preventive is conducted easier by village administration office than primary health center.

Key words: Community empowerment, health development, primary health center

\section{Pendahuluan}

Pemberdayaan masyarakat berdasarkan catatan sejarah perkembangan promosi kesehatan di Indonesia merupakan upaya yang telah lama dimulai, bahkan sejak awal pembangunan dilaksanakan di Indonesia. Istilah ini berevolusi, diawali dengan sebutan "propaganda" pada menjelang dan awal kemerdekaan, kemudian menjadi "pendidikan kesehatan masyarakat" dan "penyuluhan kesehatan masyarakat" pada tahun 1960-an. Akhirnya pada tahun 1970-an, tepatnya setelah Deklarasi Alma Ata tahun 1978, dikenal istilah "peran serta masyarakat" yang kemudian berubah menjadi "pemberdayaan

Alamat Korespondensi: Ede Surya Darmawan, Departemen AKK FKM Universitas Indonesia, Gd. F Lt. 1, Kampus Baru UI Depok 16424,

Hp.0811184713,e-mail: edesurya@ui.ac.id 
masyarakat" sebagai salah satu strategi dalam pembangunan kesehatan masyarakat. ${ }^{1-3}$ Pada tataran pelaksanaan, pemberdayaan masyarakat menjadi salah satu fungsi puskemas yang wajib dijalankan oleh seluruh puskesmas di tanah air. ${ }^{4}$

Pada sisi lain, sampai saat ini belum ada instrumen yang secara khusus dapat dipakai untuk mengukur seberapa jauh suatu kelompok masyarakat atau masyarakat di wilayah kerja sebuah puskesmas telah mencapai tingkat pemberdayaan. Hal ini tentu saja akan menyulitkan dalam penilaian dan pembuatan program untuk meningkatkan kualitas upaya pemberdayaan masyarakat. Walaupun belum memberikan instrumen yang jelas, Phil Barte, ${ }^{5}$ mengenalkan 16 elemen pemberdayaan masyarakat yang menekankan pentingnya mengukur pemberdayaan masyarakat berdasarkan potensi dan kondisi yang ada pada masyarakat.

Artikel ini ditulis berdasarkan kenyataan bahwa pemberdayaan masyarakat yang menjadi salah satu fungsi puskesmas telah lama diperkenalkan tetapi keadaan sebenarnya pada tingkat masyarakat belum diketahui. Penelitian ini bertujuan untuk mendiskusikan cara melakukan pengukuran upaya pemberdayaan masyarakat pada tingkat masyarakat serta kebijakan dan pengelolaan pemberdayaan masyarakat yang dilaksanakan di Depok dan Jakarta Selatan.

\section{Metode}

Penelitian ini menggunakan desain penelitian kuantitatif dengan metode cross sectional untuk mengukur tingkat pemberdayaan masyarakat. Tingkat pemberdayaan masyarakat merupakan variabel komposit yang diukur dari 7 komponen potensi masyarakat, yaitu 1) keberadaan tokoh masyarakat dan kader kesehatan, 2) keberadaan organisasi masyarakat termasuk upaya kesehatan bersumber daya masyarakat (UKBM), 3) kesediaan dana masyarakat, 4) kesediaan sarana dan materi dari masyarakat, 5) tingkat pengetahuan masyarakat, 6) kesediaan teknologi dari masyarakat, dan 7) pembuatan keputusan oleh masyarakat. ${ }^{2}$ Instrumen pengukuran pemberdayaan masyarakat dibuat format isian yang terdiri atas 7 unsur pemberdayaan masyarakat yang telah ditetapkan oleh Kementerian Kesehatan. Data tentang pemberdayaan masyarakat ini diperoleh berdasarkan pencatatan dari masing-masing puskesmas.

Tingkat pemberdayaan masyarakat sektor kesehatan diukur dengan menggunakan 7 potensi masyarakat. ${ }^{2,3}$ Ketujuh indikator tersebut diterjemahkan menjadi beberapa subindikator yang terdiri atas keaktifan tokoh masyarakat (4 subindikator), ketersediaan organisasi berbasis masyarakat termasuk UKBM (7 subindikator), ketersediaan dana masyarakat (6 subindikator), pemanfaatan sarana dan materi dari masyarakat (4 subindikator), penggunaan pengetahuan dari masyarakat ( 5 subindikator), teknologi dari masyarakat (4 subindikator), dan pembuatan keputusan oleh masyarakat ( 5 subindikator) sehingga total menjadi 33 subindikator yang merupakan bentuk-bentuk kegiatan yang menunjukkan upaya dan pengorganisasian masyarakat.

Populasi penelitian ini adalah seluruh puskesmas di Depok dan Jakarta Selatan. Sampel yang diambil adalah seluruh puskesmas kecamatan dan puskesmas kelurahan di Depok yakni sebanyak 32 puskesmas dan 32 puskesmas di Jakarta Selatan. Setelah dilakukan pengambilan dan pengolahan data, yang dapat diproses dari Jakarta Selatan hanya 28 puskesmas (4 puskesmas tidak terisi dengan lengkap) sehingga jumlah puskesmas yang digunakan dalam penelitian ini adalah 60 puskesmas.

Penghitungan dilakukan secara bertahap. Tahap pertama, responden mengisi daftar isian yang berisi variabelvariabel kegiatan yang termasuk ke dalam 7 potensi masyarakat. Tahap kedua, peneliti menentukan standar minimal untuk setiap kegiatan berdasarkan hasil diskusi dengan para ahli dalam bentuk penyebut untuk setiap kegiatan sesuai keberadaan kegiatan yang ada di masyarakat, yaitu pada tingkat rukun tetangga (RT), rukun warga (RW), dan kelurahan. Tahap ketiga, tingkat pemenuhan tujuh variabel potensi masyarakat ditentukan dengan berbagai kriteria (Tabel 1).

Selanjutnya tahap keempat, skor setiap tingkat pemenuhan ditentukan dengan kriteria dengan nilai antara 0 - 1. Apabila memenuhi atau lebih dari 1 maka diberikan nilai 1 dan apabila kurang dari 1 diberikan nilai hasil pembagian kegiatan jumlah RT atau RW dimaksud. Sebagai contoh, apabila di suatu wilayah kerja puskesmas mempunyai 75 tokoh masyarakat dan 50 RT maka skor puskesmas tersebut adalah 1,5 (tokoh masyarakat/RT). Apabila hasil pembagian itu diperoleh 1 atau lebih maka diberikan skor 1. Sebaliknya, apabila suatu puskemas mempunyai 50 tokoh masyarakat dan 100 RT, puskesmas tersebut mempunyai nilai 0,5 sehingga diberikan skor 0,5 . Penentuan skor akhir dilakukan dengan cara mengalikan nilai skor untuk setiap variabel dengan bobot maksimal yang telah ditentukan. Penentuan nilai bobot maksimal diberikan berdasarkan masukan dari wawancara mendalam dengan para nara sumber ahli pemberdayaan masyarakat. Hasil dari penghitungan tersebut adalah satu set data kontinum yang mendapatkan nilai $0-100$ yang merupakan skor maksimal tingkat pemberdayaan masyarakat pada suatu puskesmas.

Tahap kelima, tingkat pemberdayaan masyarakat ditentukan dengan menghitung cara mengadopsi teknik yang dipergunakan dalam menghitung indeks pembangunan manusia (IPM) yaitu nilai tertinggi dikurangi nilai terendah dibagi rentang nilai. Adopsi penghitungan tingkat keberdayaan: puskesmas dengan tingkat pemberdayaan tertinggi hingga terendah dibagi dengan nilai 
Tabel 1. Penentuan Kriteria Pemenuhan Kegiatan Pemberdayaan Masyarakat

\begin{tabular}{llc}
\hline Variabel & Kriteria Pemenuhan & Bobot \\
\hline Keaktifan tokoh masyarakat & Terpenuhi bila terdapat 1 atau lebih per RT & 20 \\
Ketersediaan organisasi kemasyarakatan dan UKBM & Terpenuhi bila terdapat 1 atau lebih per RW & 30 \\
Ketersediaan dana masyarakat & Terpenuhi bila terdapat 1 atau lebih per RW & 10 \\
Sarana dari masyarakat & Terpenuhi bila terdapat 1 atau lebih per RW & 10 \\
Pengetahuan dari masyarakat & Terpenuhi bila terdapat 1 atau lebih per RW & 10 \\
Teknologi dari masyarakat & Terpenuhi bila terdapat 1 atau lebih per RW & 10 \\
Pembuatan keputusan oleh masyarakat & Terpenuhi bila terdapat 1 atau lebih per RW & 10 \\
\hline & Jumlah Skor & $\mathbf{1 0 0}$ \\
\hline
\end{tabular}

Tabel 2. Bentuk dan Jumlah Pengorganisasian Masyarakat Bidang Kesehatan

\begin{tabular}{lll}
\hline & \multicolumn{2}{c}{ Jumlah } \\
\cline { 2 - 3 } Bentuk Pengorganisasian Masyarakat & Depok & Jakarta Selatan \\
\hline Posyandu & 892 & 1.197 \\
$\quad$ Pratama & 23 & - \\
$\quad$ Madya & 334 & 69 \\
$\quad$ Purnama & 301 & 315 \\
$\quad$ Mandiri & 234 & 813 \\
Posyandu lansia & 465 & 137 \\
Perkumpulan pemuda/remaja & 295 & 32 \\
KBKIA & 132 & 44 \\
PAUD & 190 & 174 \\
LSM/LSBM & 22 & 32 \\
Polindes & 31 & - \\
RW Siaga & 760 & 444 \\
RW Siaga aktif & 682 & 208 \\
\hline
\end{tabular}

Keterangan :

KBKIA = Keluarga Berencana Kesehatan Ibu dan Anak

PAUD $\quad=$ Pendidikan Anak Usia Dini

LSM/LSBM = Lembaga Swadaya Masyarakat/Lembaga Seni dan Budaya

Masyarakat

Polindes $\quad=$ Pondok Bersalin Desa

rentang. Dengan cara ini maka setiap puskesmas mendapatkan nilai relatif terhadap nilai puskesmas yang mempunyai nilai tingkat tertinggi sepanjang rentang yang ada sehingga dipandang lebih adil daripada nilai absolut. Berdasarkan data hasil survei, nilai tertinggi diperoleh Puskesmas Depok Jaya dengan nilai 81 dan nilai terendah diperoleh Puskesmas Beji dengan nilai 16. Rentang nilai untuk kisaran 81 - 16 adalah 65 poin. Dengan menggunakan ambang batas nilai $70 \%$ maka didapatkan batas pada nilai 45,5 ke atas untuk "tingkat pemberdayaan masyarakat baik" dan yang kurang dari 45,5 untuk "tingkat pemberdayaan masyarakat kurang". Untuk mempermudah pemahaman, peneliti membuat 2 kategori yaitu "baik" dan "kurang". Kriteria yang digunakan adalah $70 \%$ dari nilai rentang skor minimal hingga maksimal (Tabel 2).

Hasil

Bentuk upaya pengorganisasian dan pemberdayaan masyarakat sektor kesehatan di Depok dan Jakarta
Selatan umumnya mengikuti arahan yang dibuat oleh pemerintah pusat seperti posyandu dan RW Siaga. Jumlah organisasi dan UKBM yang ada di Depok lebih banyak daripada di Jakarta Selatan.

Apabila menggunakan ukuran keberadaan organisasi berbasis masyarakat termasuk UKBM seperti posyandu, diperoleh gambaran yang semakin jelas dari perbedaan pendekatan tersebut. Dari $828 \mathrm{RW}$, jumlah posyandu untuk seluruh strata di Depok adalah 889 posyandu. Dengan demikian, rasio jumlah posyandu berbanding jumlah RW di Depok adalah 1:1. Berdasarkan tingkat proporsi posyandu mandiri berbanding jumlah seluruh posyandu adalah 197:889 atau sekitar 22,2\%. Untuk Jakarta Selatan, jumlah seluruh posyandu adalah 1.197 dan bila dibandingkan dengan jumlah RW sebanyak 576 maka rasionya adalah 2,2 posyandu per RW. Berdasarkan proporsi posyandu mandiri maka di Jakarta Selatan adalah 813:1.197 atau sekitar 70\%.

Untuk keberadaan RW Siaga, di Depok terdapat 760 RW Siaga atau sekitar 92\% dari jumlah RW yang ada di Depok. Di Jakarta Selatan terdapat 444 RW Siaga atau sekitar $77 \%$ dari jumlah RW yang ada. Perkembangan RW Siaga yang lebih cepat di Depok dibandingkan Jakarta Selatan dapat menunjukkan dampak dari perbedaan pendekatan pemberdayaan masyarakat. Depok dikenal sebagai kota yang pertama kali memproklamasikan seluruh RW-nya menjadi RW Siaga yang langsung diperintah oleh Walikota Depok kepada seluruh camat, lurah, dan ketua RW.

\section{Tingkat Pemberdayaan Masyarakat}

Data kondisi pemberdayaan masyarakat berdasarkan tujuh potensi masyarakat yang ada di Depok dan Jakarta selatan kemudian dibandingkan dengan standar nilai seperti yang tertera dalam Tabel 1. Seluruh skor dari ketujuh komponen tersebut kemudian dijumlahkan untuk mendapatkan skor tingkat pemberdayaan (Tabel 3).

Untuk mengetahui tingkat pemenuhan terhadap kriteria, nilai skor dikategorikan berdasarkan kondisi kurang (bila skor kurang dari 45,5) dan baik (bila skor sama atau lebih dari 45,5). Berdasarkan kategori ini 
Tabel 3. Skor Umum Tingkat Pemberdayaan Masyarakat di Depok dan Jakarta Selatan Tahun 2010

\begin{tabular}{lccc}
\hline \multirow{2}{*}{ Wilayah } & \multicolumn{3}{c}{ Skor Tingkat Pemberdayaan } \\
\cline { 2 - 4 } & Minimal & Maksimal & Mean \\
\hline Depok & 16,00 & 81,00 & 48,90 \\
Jakarta Selatan & 20,00 & 77,00 & 41,57 \\
\hline
\end{tabular}

Tabel 4. Keadaan Umum Tingkat Pemberdayaan Masyarakat Berdasarkan Kategori Baik dan Kurang di Depok dan Jakarta Selatan

\begin{tabular}{lllll}
\hline & \multicolumn{4}{c}{ Wilayah } \\
\cline { 2 - 5 } Tingkat Pemberdayaan Masyarakat & \multicolumn{2}{c}{ Depok } & \multicolumn{2}{c}{ Jakarta Selatan } \\
\cline { 2 - 5 } & $\mathbf{n}$ & $\%$ & $\mathbf{n}$ & $\%$ \\
\hline Kurang & 13 & 40,6 & 17 & 60,7 \\
Baik & 19 & 59,5 & 11 & 39,3 \\
\hline Jumlah & $\mathbf{3 2}$ & $\mathbf{1 0 0 , 0}$ & $\mathbf{2 8}$ & $\mathbf{1 0 0 , 0}$ \\
\hline
\end{tabular}

diperoleh hasil bahwa skor tingkat pemberdayaan masyarakat di Depok menunjukkan lebih banyak yang memenuhi kategori baik dan di Jakarta Selatan lebih banyak yang memenuhi kategori kurang baik (Tabel 4).

Hasil telaah kualitatif kepada pimpinan dinas kesehatan dan suku dinas kesehatan menunjukkan terdapat perbedaan pendekatan dalam pemberdayaan masyarakat di Depok dan Jakarta Selatan. Di Depok, proses pemberdayaan masyarakat secara umum masih dipimpin oleh dinas kesehatan dan puskesmas berdasarkan surat walikota tentang pengembangan kegiatan pemberdayaan masyarakat dan RW Siaga. Di Jakarta Selatan, proses pemberdayaan lebih diserahkan kepada tingkat aktivitas RT dan RW di bawah pimpinan kepala kelurahan. Kondisi di Jakarta Selatan seperti ini sejalan dengan penerapan Peraturan Daerah DKI Jakarta No. 4/2009 tentang Sistem Kesehatan Daerah yang ditindaklanjuti dengan Peraturan Gubernur DKI Jakarta No. 147/2009 yang menyebutkan bahwa fungsi kesehatan masyarakat dan pemberdayaan masyarakat menjadi tugas pokok dan fungsi kantor kelurahan sehingga bukan lagi tugas pokok dan fungsi puskesmas.

\section{Pembahasan}

Perbedaan kondisi pemberdayaan masyarakat, termasuk organisasi dan UKBM salah satunya disebabkan oleh perbedaan pendekatan. Depok terlihat lebih menggunakan pendekatan directed atau diarahkan sementara Jakarta Selatan cenderung menggunakan pendekatan nondirected. Informan dari Depok mengonfirmasikan hasil ini dengan menyatakan bahwa setiap kegiatan pem- berdayaan masyarakat bidang kesehatan masih difasilitasi oleh dinas kesehatan. Hal ini berbeda dengan kondisi di Jakarta Selatan yang menyatakan bahwa pemberdayaan masyarakat difasilitasi oleh kelurahan sehingga RW dan RT bekerja sama dengan puskesmas. Saat ini berdasarkan ketentuan yang berlaku di DKI Jakarta, fungsi upaya kesehatan masyarakat termasuk pemberdayaan masyarakat telah dialihkan dari puskesmas ke kantor kecamatan dan kantor kelurahan.

Berdasarkan sudut pandang variasi kegiatan, secara umum di Depok dan Jakarta Selatan masih sama, hanya saja Jakarta Selatan saat ini memiliki kekhasan pemberdayaan masyarakat dalam bentuk Gerakan Jumat Sehat yaitu gerakan dokter praktik swasta turun mengunjungi 10 rumah warga bersama dengan kader Pemberdayaan dan Kesejahteraan Keluarga (PKK) setempat dua kali setiap bulan. Upaya ini merupakan imbauan walikota agar para dokter yang berpraktik swasta di Jakarta Selatan memberikan bakti kepada masyarakat dalam bentuk kunjungan untuk memberikan upaya edukasi dan penemuan kasus secara langsung. Bentuk gerakan seperti ini hanya terdapat di Jakarta Selatan.

Berdasarkan upaya yang dilakukan oleh Walikota Depok dalam pengembangan RW Siaga dan Walikota Jakarta Selatan dalam pelaksanaan Gerakan Jumat Bersih dapat ditarik pelajaran bahwa penting untuk meletakkan upaya percepatan proses pembangunan kesehatan masyarakat pada pimpinan daerah. Sebab, pimpinan daerah merupakan aktor yang memiliki peran sangat besar karena posisinya (ex officio) dalam mengeluarkan perintah atau membuat kebijakan operasional termasuk penyediaan sumber daya. Kenyataan ini senada bahwa kepemimpinan dan politik kesehatan penting dalam pembangunan kesehatan masyarakat. Sementara itu, variasi bentuk pemberdayaan masyarakat di Depok dan Jakarta Selatan juga memberikan pelajaran bahwa upaya yang berbeda dan merupakan kekhasan dari masingmasing daerah telah berlangsung pada era otonomi daerah sekarang ini. Melihat kenyataan ini, untuk keperluan perluasan dan peningkatan upaya pembangunan kesehatan dan khususnya pemberdayaan masyarakat yang merupakan salah satu strategi pembangunan kesehatan secara nasional di masa yang akan datang diperlukan berbagai riset operasional untuk mendapatkan pembelajaran efektivitas dan perluasan informasi bagi kabupaten/kota lain di Indonesia.

Apabila dibandingkan dengan berbagai literatur yang ada, ketujuh indikator yang kemudian menjadi 33 subindikator pada dasarnya telah sesuai atau mendekati. Pemberdayaan masyarakat merupakan upaya mengembangkan masyarakat agar lebih berkemampuan menangani persoalan kesehatan masyarakat yang dihadapi. Untuk mencapai hal tersebut disarankan penggunaan sembilan ranah operasional sebagai fokus dalam membuat peren- 
canaan strategis atau program, yakni memperbaiki partisipasi pihak-pihak terkait (stakeholder), meningkatkan kemampuan menilai masalah, mengembangkan kepemimpinan masyarakat setempat, membangun keberdayaan struktur organisasi yang ada, memperbaiki mobilisasi sumber daya, memperkuat hubungan antara berbagai organisasi lain dengan masyarakat, meningkatkan kemampuan para pihak terkait untuk "bertanya mengapa?", meningkatkan pengawasan para pihak terkait terhadap manajemen program, dan membuat hubungan yang lebih setara dengan pihak-pihak luar terkait. 6,7

Agar pembinaan organisasi berbasis masyarakat UKBM ini berjalan baik diperlukan penataan pengorganisasian. Selama ini, posyandu berjalan dengan keputusan dan peraturan kementerian dalam negeri dan yang terbaru adalah Peraturan Menteri Dalam Negeri No. 54 Tahun 2007 tentang Pedoman Pembentukan Kelompok Kerja Operasional Pembinaan Pos Pelayanan Terpadu. Berdasarkan peraturan ini maka dibentuklah Kelompok Kerja Operasional Posyandu dari tingkat pusat, provinsi, kabupaten/kota, kecamatan, hingga kelurahan/desa. Tahun 2006, menteri kesehatan menerbitkan Surat Keputusan No. 564 tentang Pedoman Pengembangan Desa Siaga yang juga meminta pembentukan satuan tugas dan fasilitator Desa Siaga. Upaya diversifikasi ini baik, tetapi di tengah keterbatasan sumber daya dan pendanaan diperlukan upaya membangun yang sinergis di lapangan. Petugas dan kader yang bekerja mengembangkan kegiatan posyandu dan Desa Siaga adalah orang yang sama. Perlu upaya penyamaan kebijakan termasuk penamaan program Desa Siaga yang umumnya belum dikenal oleh para pembuat kebijakan di daerah. ${ }^{8}$

Berdasarkan kenyataan ini, kementerian kesehatan perlu dengan cepat melakukan sosialisasi setiap perubahan dan kebijakan baru yang telah dikembangkan. Sosialisasi dilakukan kepada pemerintah daerah dan instansi tingkat pusat terkait. Dengan pemikiran system thinking yang merekomendasikan pemahaman setiap persoalan sebagai sebuah sistem yang dinamis, pembahasan lebih lanjut tentang pengorganisasian upaya kesehatan berbasis masyarakat menunjukkan keterkaitan tata kelola pemerintahan pada tingkat desa/kelurahan. Upaya mendorong pemberdayaan masyarakat bidang kesehatan tidak cukup hanya mengandalkan satu komponen sistem yang bekerja pada upaya pemberdayaan masyarakat. ${ }^{9}$ Berbagai kebijakan yang ada di tingkat kelurahan/desa merupakan peluang untuk meningkatkan kesejahteraan melalui upaya pemberdayaan masyarakat pada sektor kesehatan secara bersama. Pada sisi lain, persoalan ini mendapatkan kendala akibat persoalan kapasitas organisasi puskesmas yang belum disiapkan untuk fungsi pemberdayaan masyarakat secara baik. Semakin jelas bahwa upaya penguatan institusi kelurahan/desa diperlukan agar semakin mampu melaksanakan tugas-tugas yang dibebankan termasuk mengoordinaskan pemberdayaan masyarakat bidang kesehatan.

Pemberdayaan masyarakat pada bidang kesehatan harus dilihat sebagai upaya komprehensif membangun masyarakat secara langsung di tingkat kelurahan dan desa. Untuk mempercepat proses pemberdayaan masyarakat, tanggung jawab upaya tersebut perlu diletakkan pada pimpinan daerah, kelurahan, dan desa. Pimpinan daerah berperan sangat besar membuat kebijakan termasuk penyediaan sumber daya dan memerintahkan langsung kepada aparat di tingkat kelurahan dan desa. Peran pemberdayaan masyarakat seharusnya ada pada pemerintah daerah dan institusi terkait di bawahnya, meliputi kantor kecamatan dan pemerintahan desa/kelurahan sesuai kewenangan yang diberikan. Institusi kesehatan masyarakat yang meliputi dinas/suku dinas kesehatan dan puskesmas tetap berperan memberi masukan pada penerapan fungsi penilaian, mengembangkan kebijakan masyarakat sehat dan membuat lingkungan kondusif, serta memberi jaminan agar setiap upaya pembangunan menjadikan kesehatan masyarakat sebagai tujuan.

\section{Kesimpulan}

Instrumen pengukuran tingkat pemberdayaan masyarakat yang dikembangkan merupakan instrumen awal yang dapat digunakan untuk menilai tingkat keberdayaan masyarakat pada tingkat komunitas. Instrumen ini masih dapat terus diperbaiki dan dikembangkan pemanfaatannya pada masa yang akan datang. Hasil analisis dari pemanfaatan instrumen ini telah menunjukkan bahwa tingkat pemberdayaan masyarakat pada wilayah kerja puskesmas di Depok umumnya lebih banyak yang memenuhi kategori baik dan untuk puskesmas di Jakarta Selatan lebih banyak yang termasuk kategori kurang. Penelitian ini juga menunjukkan bahwa pemberdayaan masyarakat merupakan upaya multisektor dengan titik pengarahan pada pemerintah daerah sebagai penanggung jawab pemerintah dan pembangunan termasuk untuk sektor kesehatan. Hasil uji coba di Provinsi DKI Jakarta menunjukkan bahwa upaya pemberdayaan masyarakat, dan promotif-preventif lebih mudah dilakukan oleh kantor kelurahan daripada puskesmas.

\section{Saran}

Perubahan atau pembaruan kebijakan dengan sosialisasi yang memadai perlu ditindaklanjuti. Sosialisasi harus segera dilakukan agar terjadi kesamaan dan keselarasan dalam memakai penamaan sebuah kebijakan baru seperti desa/kelurahan/RW Siaga. Agar lebih mudah dipahami oleh pemerintah daerah, kebijakankebijakan yang terkait dengan pemberdayaan masyarakat khususnya penguatan kapasitas pemerintahan tingkat de- 
sa dan kelurahan perlu diintegrasikan pada tataran kementerian di tingkat pusat dalam kerangka pengembangan dan penguatan otonomi daerah. Kebijakan puskesmas perlu diperjelas agar didukung dengan sumber daya yang memadai termasuk penguatan kapasitas manajerial dari para petugas puskesmas agar semakin mampu melakukan fungsi pemberdayaan masyarakat, menguatkan pemahaman terhadap tata kelola manajemen di tingkat desa/kelurahan, dan mengembangkan kemampuan dalam membangun aliansi, serta mendorong partisipasi komunitas. Untuk itu, berbagai program pelatihan dan pendidikan terkait harus diarahkan untuk dapat mengatasi persoalan pada tataran praktis di tingkat masyarakat. Dengan melihat keberhasilan uji coba di Jakarta dan terus meningkatnya keadaan sosial ekonomi masyarakat Indonesia maka perlu kebijakan dan langkah nyata untuk lebih memfokuskan pelayanan puskesmas agar semakin baik dalam memberikan pelayanan kesehatan dan mengoptimalkan pemberdayaan masyarakat yang lebih merepresentasikan pemerintah daerah melalui kecamatan dan kelurahan.

\section{Daftar Pustaka}

1. Kementerian Kesehatan Republik Indonesia. Pembangunan kesehatan masyarakat di Indonesia. Jakarta: Kementerian Kesehatan Republik Indonesia; 1990.
2. Kementerian Kesehatan Republik Indonesia, United Nation Emergency Children's Fund. Panduan umum pemberdayaan masyarakat. Jakarta: Kementerian Kesehatan Republik Indonesia, United Nation Emergency Children's Fund; 1999.

3. Kementerian Kesehatan Republik Indonesia. Perkembangan dan tantangan promosi kesehatan di Indonesia: dari propaganda sampai promosi kesehatan. Jakarta: Kementerian Kesehatan Republik Indonesia; 2009.

4. Kementerian Kesehatan Republik Indonesia. Keputusan menteri kesehatan Republik Indonesia no. 128 tahun 2004 tentang kebijakan dasar pusat kesehatan masyarakat. Jakarta: Kementerian Kesehatan Republik Indonesia; 2004.

5. Barte P. Enam belas elemen pemberdayaan masyarakat. Yarsi D: penerjemah. [diakses tanggal 20 Juni 2008]. Diunduh dari: http:// www.scn.org/cds/mpfc/modules/mea-16in.htm.

6. Laverack G. Building capable communities: experiences in a rural Fijian context. Health Promotion International Journal. 2003; 18 (2).

7. Laverack G, Nina W. Measuring community empowerment: a fresh look of organizational domains. Health Promotion International Journal. 2001; 16 (2).

8. Abdurrachman. Kajian kesiapan Petugas dan masyarakat dalam pengembangan desa siaga. Jakarta: Kementerian Kesehatan Republik Indonesia; 2007.

9. Junadi P. Jalan cerdas menuju sehat. Proseding pidato pengukuhan guru besar Fakultas Kesehatan Masyarakat Universitas Indonesia. Depok; 2007. 